\title{
Strategi Proses Recruitment PT Pelindo Daya Sejahtera Dalam Menghadapi Pandemic Covid-19
}

\author{
${ }^{1}$ Denny Samba, ${ }^{2}$ Suryanto \\ Universitas Airlangga, Surabaya, Indonesia \\ Email:1enny.samba-2019@pasca.unair.ac.id
}

(Diterima: Juli 2021; Direvisi: Agustus 2021; Dipublikasikan: September 2021)

\begin{abstract}
ABSTRAK
Pandemi covid-19 semakin meluas di seluruh dunia. Secara tidak langsung wabah ini berdampak pada dunia usaha. Perusahaan dituntut inovatif dalam upaya melakukan pencegahan penyebaran virus covid-19. Oleh karena itu penting bagi PT PDS mencoba strategi baru dalam proses rekrutment dan seleksi untuk mencegah kerumunan. Penulis telah melakukan penelitian terkait strategi yang dilakukan oleh PT PDS. Tujuan penelitian ini adalah untuk menemukan strategi yang tepat untuk proses recruitment dan seleksi dalam menghadapi pandemic covid-19. Metode penelitian yang digunakan dalam penelitian ini adalah kualitatif dengan menggunakan metode deskriptif. Penelitian ini menyimpulkan bahwa inovasi erecruitment tepat dilaksanakan untuk proses recruitment dan seleksi calon pegawai PT PDS dalam menghadapi pandemic covid-19. Dalam pelaksanaan e-recruitment di PT PDS sangat dibutuhkan ketrampilan staff recruitment dalam mengoperasikan penggunaan media teknologi informasi dan komunikasi.
\end{abstract}

\section{Kata Kunci: Pandemi COVID-19, E-Recruitment}




\section{PENDAHULUAN}

Wabah virus covid-19 semakin meluas di seluruh penjuru dunia tidak terkecuali Indonesia. Pada tanggal 2 Maret 2020, Bapak Presiden Jokowi mengumumkan bahwa ada 2 orang yang positif terserang corona dan sejak saat itu mulai bermunculan dan bertambah jumlah korban yang berstatus suspek covid-19. Sebagai upaya pencegahan penyebarluasan virus, pada tanggal 16 Maret 2020 Bapak Presiden tidak mengambil langkah lockdown tetapi lebih menghimbau semua warga untuk melakukan social distancing atau menjaga jarak sosial supaya lebih banyak beraktifitas di dalam rumah. Sampai dengan saat ini tren sebaran kasus covid-19 masih sangat tinggi baik secara global maupun di Indonesia. Menurut update data dari website covid : https://covid19.go.id/ pada tanggal 07 Juni 2021, terkonfirmasi positif global sebanyak 173.006.553 dan terkonfirmasi positif di Indonesia sebanyak 1.863.031.

\section{Data Sebaran}

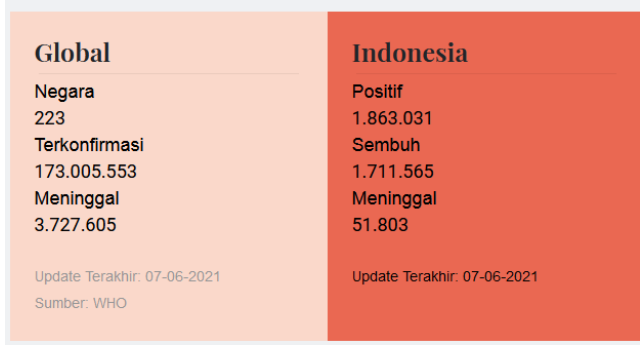

Gambar 1. Data Sebaran

Berdasarkan himbauan Bapak Presiden tersebut, semua aktifitas sekolah, aparatur sipil negara, pegawai badan usaha milik negara dan pegawai swasta tidak diperkenankan untuk berangkat ke sekolah atau tempat kerja dalam membantu meminimalisir penyebaran virus COVID 19. Berbagai upaya dilakukan untuk meminimalisir penyebaran virus covid-19, melalui penerapan pola kerja work from home, penyemprotan desinfektan (anti kuman) ke semua bagian dan lokasi perusahaan, penyemprotan desinfektan ke tubuh karyawan saat akan memasuki area perusahaan, penerapan anjuran rajin cuci tangan, penyediaan hand sanitizer, pemakaian masker dan penyuntikan vaksin covid-19.

PT Pelindo Daya Sejahtera (PT PDS) merupakan anak perusahaan dari PT Pelindo III (Persero) yang fokus dan bergerak di bidang penyedia tenaga kerja. Proses bisnis PT PDS tidak lepas dari komitmen manajemen dalam upaya pencegahan penyebarluasan virus covid-19 khususnya di lingkungan kerja. Seluruh elemen PT PDS saling support dan saling mengingatkan dalam mencegah tersebarnya virus covid-19.

Dalam melakukan pencegahan penyebarluasan virus covid-19 divisi SDM dan Umum turut berpartisipasi dengan mencoba teknik baru dalam proses pelaksanaan rekrutmen pegawai baru. Proses rekrutmen dan seleksi yang biasanya dilakukan dengan mengundang kandidat dalam jumlah banyak untuk dilakukan serangkaian seleksi tes dan interview akan berganti dengan penggunaan media komunikasi dan informasi melalui e-recruitment.

Dalam hal ini penulis mengambil sample penelitian terhadap staff recruitment PT PDS. Tujuan dari penelitian ini adalah untuk menentukan strategi yang tepat dalam proses recruitment selama menghadapi pandemic covid-19. Hal ini juga bertujuan untuk memetakan kemampuan minimal yang harus 
dimiliki oleh seorang staff recruitment dalam proses adaptasi baru proses recruitmen ketika pandemic covid-19 supaya dapat menyelesaikan tugas dan tanggung jawabnya dengan baik. Hasil dari penelitian juga dapat dijadikan sebagai bahan referensi dalam pelaksanaan program pelatihan sebagai wadah bagi staff recruitment untuk membantu mengembangkan kompetensi yang masih kurang.

\section{TINJAUAN PUSTAKA}

\section{Industri 4.0}

Dengan adanya era industry 4.0, praktik manajemen berubah secara cepat mengikuti perkembangan zaman. Akibatnya, kepemimpinan dan budaya organisasi juga berubah. Perubahan ini disebabkan oleh tiga tren, yakni merosotnya manajemen tradisional, revolusi teknologi internet dan munculnya generasi milenial yang memasuki dunia kerja. Dalam kasus ini, akan dibahas berbagai inovasi yang bisa dilakukan dalam proses rekrutmen dan seleksi karyawan pada masa social distancing.

\section{Rekrutmen dan Seleksi}

Menurut Flippo (1984), rekrutmen adalah proses pencarian tenaga kerja yang dilakukan secara seksama sehingga dapat merangsang mereka untuk mau melamar jabatan-jabatan tertentu yang ditawarkan oleh organisasi. Veithzal Rivai (2009:1) mengemukakan rekrutmen adalah proses untuk menentukan dan menarik calon pelamar, yang mampu bekerja pada suatu perusahaan. Maltis et el (2010:112) menyatakan, rekrutmen pegawai adalah proses atau tindakan yang dilakukan oleh manajemen perusahaan untuk mendapatkan tambahan pegawai.

Menurut Ryan Martian dalam bukunya HRM 4.0 proses rekrutmen bisa dilakukan dengan berbagai cara yaitu :

a) Membagi informasi lowongan kerja di sosial media (facebook, Instagram, website dsb),

b) Mengiklankan lowongan kerja di media elektronik dan media cetak,

c) Membagi informasi lowongan kerja di biro tenaga kerja yang menyediakan tenaga kerja siap pakai,

d) Rekomendasi dari pegawai yang ada dalam organisasi.

e) Membagi informasi lowongan kerja di sekolah atau perguruan tinggi.

f) Membagi informasi lowongan kerja di himpunan-himpunan profesi.

g) Menyelenggarakan open house.

h) Mencuri pegawai dari organisasi lain.

Sedangkan menurut Barlian T. Winarta dalam bukunya yang berjudul 500 ways to multiply your people's productivity, proses rekrutmen bisa dilakukan dengan cara : Mencari karyawan dari orang-orang yang dikenal, Menggunakan referensi dari pihak yang kita percaya, Campus recruitment, Iklan di media massa, Melalui internet, Kerjasama dengan biro hubungan alumni / kemahasiswaan di kampus, Job fair, Melalui Depnaker; Iklan di koran; Talent pool; Radio; Brosur; Iklan di angkot; Facebook; Facebook info loker terbaru; 
Facebook info loker community; Facebook info lowongan kerja; Linked in; Blog; Twitter; Twitter @info_loker; Twitter @loker_Dir; Referensi karyawan; Referensi manajemen; Serikat buruh; Agen tenega kerja pemerintah; Open house; Dengan cara jobvite; Lowongan-pekerjaan.com; Bursa lowongan pekerjaan; Perluas relasi; Agen perekrutan; Agen untuk pencarian executive; Jalur telepon; Open days; Iklan televisi; Balai latihan keterampilan; Bertanya kepada mitra bisnis; Outsourching company; Rekrutmen internal; Seminar loker; Melalui pengumuman karyawan.

Hasibuan

menyatakan Seleksi penerimaan karyawan baru bertujuan untuk memperoleh karyawan yang memiliki kriteria sebagai berikut : karyawan yang qualified dan potensial, dapat bekerja secara mandiri, mempunyai perilaku dan budaya malu, jujur dan berdisiplin, cakap dengan penempatannya yang tepat, terampil dan bersemangat dalam bekerja, karyawan memenuhi persyaratan undang-undang perburuhan, dapat bekerja sama baik secara vertikal maupun horizontal, dinamis dan kreatif, inovatif dan bertanggung jawab. Tujuan berikutnya adalah memiliki karyawan yang loyal dan berdedikasi tinggi serta mengurangi tingkat absensi dan turnover karyawan.

\section{E-Recruitment}

Menurut Dysart (1999) dan Taylor (2011) e-recruitment memiliki definisi proses penerimaan kandidat karyawan baru yang sesuai dengan persyaratan melalui media elektronik yang tehubung secara online. Menurut Parry (2006), E rekrutmen adalah penggunaan internet untuk menarik karyawan yang potensial ke dalam suatu organisasi, termasuk di dalamnya adalah penggunaan dari situs perusahaan itu sendiri, organisasi dan penggunaan papan pengumuman lowongan pekerjaan komersial secara online.

Menurut Galanaki (2002), erecruitment didefinisikan dengan proses recruitment secara online mengacu pada posting lowongan di situs web perusahaan atau website vendor rekrutment online, dan memungkinkan pelamar untuk mengirimkan resume mereka secara elektronik melalui e-mail atau dalam beberapa format elektronik.

\section{METODE PENELITIAN}

Penelitian ini merupakan penelitian deskriptif kualitatif, yang artinya metode penelitian yang digunakan adalah analisis kualitatif untuk mendapatkan gambaran yang jelas dan mendalam tentang bisnis proses rekrutmen yang dilakukan. Penulis mengambil sampel penelitian terhadap staff recruitment PT PDS. Disebut metode kualitatif karena data dapat dikumpulkan dan analisisnya sangat kualitatif (Sugiono dalam Meldiana et al, 2020).

Analisis data dilakukan dalam upaya untuk mengetahui bagaimana staff recruitment dalam melaksanakan tugas dan kewajiban serta untuk mendapatkan informasi lain sebagai 
penunjang penulis melakukan wawancara atau interview langsung dengan staff rekruitmen PT PDS.

\section{HASIL PENELITIAN}

Saat ini merupakan era industri 4.0, dimana praktik manajemen berubah secara cepat mengikuti perkembangan zaman. Akibatnya, kepemimpinan dan budaya organisasi di setiap perusahaan juga dituntut berubah dan beradaptasi dengan cepat. Dalam penelitian ini, dibahas terkait inovasi yang bisa dilakukan dalam bisnis proses rekrutmen dan seleksi karyawan dengan menjaga social distancing di PT Pelindo Daya Sejahtera.

Dari hasil wawancara penulis dengan staff rekruitmen PT PDS, di dapat informasi bahwa di dalam proses adaptasi dengan perubahan lingkungan yang cepat, menuntut bisnis proses rekruitmen pegawai untuk meyesuaikan. Informasi lain yang penulis dapat dari narasumber adalah bahwa dalam proses rekruitment PT PDS memiliki keuntungan dengan jumlah pelamar yang sangat besar setiap membuka lowongan pekerjaan. Para pelamar tertarik untuk melamar dikarenakan status PT PDS adalah salah satu dari anak usaha dari perusahaan BUMN Pelindo III (Persero). Dengan jumlah pelamar yang sangat besar, menjadi tantangan tersendiri PT PDS dalam melakukan proses seleksi, sangat penting untuk dapat dilakukan proses e-recruitmen pada masa pandemic covid-19.

Dalam proses implementasi ERecruitmen dalam proses recruitment dan seleksi pegawai PT PDS maka perlu diatur kembali beberapa cara baru dalam setiap tahapan prosesnya.
Staff rekruitmen harus mampu beradaptasi dengan lingkungan dan teknologi yang baru. Beberapa pembaharuan yang mesti dilakukan antara lain :

a) Sarana informasi lowongan pekerjaan yang dipakai oleh PT PDS adalah melalui Media Elektronik. Media Elektronik khususnya media online yang dipakai berupa instagram story, posting feed instagram resmi dari PT PDS dan PT Pelindo 3 (Group), media whatsapp group, wahatsapp story, dan media website resmi yang dikelola oleh PT PDS. Selain itu media elektronik lain adalah melalui situs job posting pihak ketiga seperti Jobstreet dan Jobsdb untuk ditujukkan ke pelamar umum dan freshgraduate

b) Pemindaian (scanner) pelamar, perusahaan dapat melihat dan menyaring resume para pelamar melalui kriteria dan persyaratan wajib yang telah ditetapkan diawal atau criteria umum yang harus dipenuhi oleh para calon pekerja.

- Proses recruitment existing: masih sering ditemukan pelamar yang datang secara langsung ke kantor PT PDS untuk menyerahkan data secara hardcopy dan tidak melamar melalui website yang disediakan.

- E Recruitmen: calon pegawai yang melamar wajib mengisi pada link website yang disediakan dan melampirkan syarat-syarat pendaftaran secara lengkap dengan mengupload pada menu yang tersedia.

c) Identifikasi pelamar, perusahaan mengidentifikasi lebih lanjut 
mengenai pelamar, melihat dari Curriculum Vitae (CV).

- Proses recruitment existing: perusahaan mengecek lebih lanjut $\mathrm{CV}$ pelamar secara manual sebagai bahan pertimbangan dalam meloloskan pelamar dalam seleksi administrasi.

- E Recruitmen: perusahaan hanya cukup melakukan filterisasi data pelamar.

d) Mengelola surat lamaran, perusahaan merespon cepat terhadap calon pekerja yang diinginkan untuk menempati posisi tersebut.

- Proses recruitment existing: perusahaan menghubungi satu per satu dengan telepon untuk karyawan yang lolos seleksi administrasi.

- E Recruitmen: perusahaan mengirimkan email kepada para pelamar yang lolos dalam tahap seleksi administrasi online yang nantinya akan dipanggil ke perusahaan untuk tahap seleksi berikutnya.

e) Proses Psikotes

- Recruitmen existing: karyawan dipanggil dan dikumpulkan di satu ruangan yang telah disediakan dan serentak melakukan serangkaian tes psikotes secara bersamaan dengan metode tulisan tangan manual.

- E Recruitmen: perusahaan membuat jadwal tes psikotes secara online dan peserta dapat menyiapkan computer beserta internet, sehingga seketika tes selesai dilakukan peserta dapat langsung melihat hasil tes masing-masing. f) Proses Wawancara

- Recruitmen existing: para calon karyawan dipanggil dan melakukan wawancara secara langsung dengan manager atau direktur perusahaan dengan bertatap muka.

- E Recruitmen: perusahaan akan membuat jadwal interview wawancara, dengan memanfaatkan video call online.

g) Proses Medical Check up, dilakukan di klinik atau rumah sakit yang telah ditunjuk dengan pertimbangan keamanan calon pegawai.

\section{PENUTUP \\ Simpulan}

Proses rekruitmen existing yang dilakukan oleh PT PDS masih menggunakan metode lama yang umumnya digunakan oleh seluruh perusahaan dalam merekrut pegawai. Pemindaian (Scanner) Pelamar, dilakukan dengan manual hard copy $\mathrm{CV}$ yang dikumpulkan secara manual satu persatu, kemudian menghubungi dengan telepon, dan menjadwalkan untuk datang ke kantor dalam seleksi tahap berikutnya (psikotes dan wawancara). Berbagai upaya pembaharuan proses kerja rekruitmen dan seleksi perlahan-lahan saat ini sudah mencoba untuk dapat beradaptasi dengan penggunaan teknologi informasi dan komunikasi.

Dalam meminimalisir wabah virus covid 19 yang menuntut untuk menghindari keramaian, dan menjaga jarak antar individu (sosial distance), maka muncul inovasi baru di dalam proses recruitmen yakni melalui ERecruitment. Dengan adanya inovasi E-Recruitment proses recruitment PT 
PDS akan menjadi lebih optimal dan upaya pemerintah untuk tetap \#Dirumahsaja juga tercapai. Keuntungan lain dengan penerapan erecruitment ini adalah dapat meminimalisir sumber daya selama proses rekruitmen.

Tabel 1.

\begin{tabular}{|l|l|c|c|c|}
\hline $\begin{array}{l}\mathrm{N} \\
\mathrm{o}\end{array}$ & $\begin{array}{l}\text { Recruitm } \\
\text { ent } \\
\text { Metods }\end{array}$ & $\begin{array}{c}\text { Co } \\
\text { st }\end{array}$ & $\begin{array}{c}\text { Numb } \\
\text { er of } \\
\text { manpo } \\
\text { wer }\end{array}$ & $\begin{array}{c}\text { Lo } \\
\text { ng } \\
\text { Ti } \\
\text { me }\end{array}$ \\
\hline 1 & $\begin{array}{l}\text { E- } \\
\text { Recruitme } \\
\text { nt }\end{array}$ & $\sqrt{ }$ & - & - \\
\hline 2 & Job Fair & $\sqrt{ }$ & $\sqrt{ }$ & $\sqrt{ }$ \\
\hline 3 & Walk-in & - & $\sqrt{ }$ & $\sqrt{ }$ \\
\hline 4 & $\begin{array}{l}\text { Advertise } \\
\text { ment }\end{array}$ & $\sqrt{ }$ & - & - \\
\hline
\end{tabular}

\section{Saran}

Inovasi teknologi ERecruitment segera di laksanakan dan di terapkan dalam proses recruitmen pegawai dengan memanfaatkan aplikasi terbaru dan terupdate yang memudahkan calon pegawai dan perusahaan, sebagai langkah konkrit dalam memutus dan meminimalisir dampak dari virus Covid 19

\section{DAFTAR PUSTAKA}

Affandi, A., et al. (2020). Optimization of MSMEs Empowerment in Facing Competition in the Global Market during the COVID-19 Pandemic Time. Systematic Reviews in Pharmacy, 11(11), 1506-1515.

Anisah, N., Anton, A., \& Radiyah, U. (2016). Rancangan Sistem Informasi E-Recruitment Berbasis Web Pada Pt. Geoservices. Prosisko: Jurnal Pengembangan Riset Dan
Observasi Sistem Komputer, $3(2)$.

Dysart, J. (1999). Hr Recruiters Build Interractivity Into Web Sites, Hr Magazine 44 (3).

Edwin B. Flippo (1984), Manajemen Personalia, Erlangga, Surabaya. Galanaki, R. (2002). Cretomania : Modern Desires For The Minoan Past, Northwestern University Press.

Handoko, T. Hani. 2008. Manajemen Personalia Dan Sumber Daya Manusia. Liberty: Yogyakarta

Hasibuan. 2005. Manajemen Sumber Daya Manusia. Jakarta: Bumi Aksara.

Martian, Ryan. (2019). Hrm 4.0 : Literia Media Tama

Nanda, K. D., \& Prasetya, A. (2017). Efektifitas Penerapan Metode Rekrutmen Online (ERecruitment) (Studi Pada Pt Industri Kereta Api (Inka)Jawa Timur). Jurnal Administrasi Bisnis, 53(1), 96104.

Rivai, Veithzal. (2009). Manajemen Sumber Daya Manusia Untuk Perusahaan Dari Teori Ke Praktik. Jakarta: Raja Grafindo Persada.

Sunarsi, D., Suryani, N. L., \& Jati, W. (2020). Covid-19 Pandemic Analysis Toward Productivity Giving Layoffs Effect in The Company of Industrial Sector around South Tangerang. Prosiding ICoISSE, 1(1), 472481.

Winarta, Barlian. (2017). 500 Ways To Multiply Your People's Productivity: Elex Media Komputindo. 